\title{
Evaluation of Dose-Dependent Effects of Nesfatin-1 in Pentyleneterazole Induced Seizures in Mice
}

\section{(1) Özlem ERGÜL ERKEÇ}

Department of Physiology, Van Yüzüncü Yıl University Faculty of Medicine, Van, Turkey

\begin{abstract}
Objectives: It is well known that neuropeptides have powerful modulator effects on inhibitory and excitatory systems in the brain. Serum nesfatin-1 levels are reported to be increased in epileptic patients and experimental models of epilepsy. However, the effects of nesfatin-1 administration on acute pentylenetetrazole (PTZ)-induced seizures are unknown. The aim of this study is to investigate the dose-dependent effects of nesfatin-1 in PTZ-induced acute seizure model in mice.

Methods: Animals were divided into six groups: (1) Control, (2) PTZ, (3, 4, 5, 6) PTZ+Nesfatin-1 (1, 10, 20 veya $40 \mu \mathrm{g} / \mathrm{kg}$, i.p). Physiological saline (PS, $1 \mathrm{~mL} / \mathrm{kg}$, i.p) was administrated to the mice in the control group. Nesfatin-1 or PS was administered to the experimental groups. Thirty minutes after injection of nesfatin-1 or SF, PTZ ( $80 \mathrm{mg} / \mathrm{kg}$, i.p) was injected into all experimental groups to induce epileptic seizures. Latencies of the first myoclonic jerk (FMJ), generalized clonic seizures (GCS), and tonic generalized extension (TGE), and duration of TGE were determined after PTZ injection.

Results: No significant difference was found between the groups in terms of latencies of FMJ, GCS, TGE, and duration of TGE.

Conclusion: Nesfatin-1 did not show anti or pro-convulsant effects at all doses. In conclusion, our data demonstrated that nesfatin-1 administration had no anti/pro-convulsant effect on PTZ $(80 \mathrm{mg} / \mathrm{kg})$ induced acute seizures in mice.
\end{abstract}

Keywords: Neuropeptide; pentylenetetrazole; PTZ; seizure.

Cite this article as: Ergül Erkeç Ö. Evaluation of Dose-Dependent Effects of Nesfatin-1 in Pentyleneterazole Induced Seizures in Mice. Epilepsi 2021;27:73-77.

\section{Giriş}

Epilepsi dünya çapında 70 milyon insanı etkileyen yaygın ve kronik bir nörolojik bozukluktur. ${ }^{[1]}$ Epilepsi hastalarının üçte birinde ilaca dirençli nöbetler görülmektedir. ${ }^{[2]}$ illaca dirençli epilepsi artmış morbidite, mortalite ve düşük yaşam kalitesi ile ilişkilidir. ${ }^{[2]}$ Epilepsi hastalığı, toplumda kayda değer bir ekonomik yüke de neden olmaktadır. ${ }^{[3]}$

Epilepsi, tekrarlayan, provoke edilmemiş nöbetler ile karakterizedir. ${ }^{[4]}$ Bu nöbetler, eksitasyon ve inhibisyon arasındaki hassas dengenin bozulması sebebiyle oluşan beyinde anormal ve eşzamanlı nöronal aktiviteden kaynaklanmak-

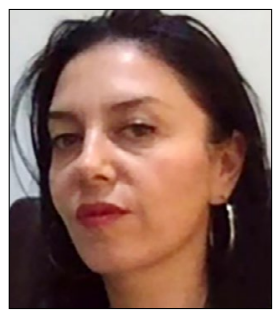

Corresponding author Özlem ERGÜL ERKEÇ, PhD e-mail oerkec@gmail.com

Received 12.10.2020

Accepted 17.12.2020

Online date 02.04.2021

Content of this journal is licensed under a Creative Commons Attribution-NonCommercial 4.0 International License.

Özlem ERGÜL ERKEÇ, PhD tır. ${ }^{[5]}$ Tüm epilepsi türleri, sinir hücrelerinin eksitatör-inhibitör dengesinin, merkezi sinir sistemine yayılabilen hipereksitabilitiye neden olan eksitasyona doğru kaymasından kaynaklanmaktadır. ${ }^{[6]}$ Nöropeptitlerin nöbetleri ve epilepsiyi modüle etmede önemli bir role sahip olduğu bildirilmektedir. ${ }^{[4]}$ Nöropeptidler, klasik uyarıcı ve inhibe edici nörotransmiterlerin etkisini modüle ederek bu dengesizliğe katkıda bulunabilirler. $^{[5]}$ Bunu nörotransmitterlerin; salınımlarında değişiklik yaparak, reseptör seviyesinde etkilerini regüle ederek ve dolayısıyla inhibisyon ve eksitasyon arasındaki dengeyi etkileyerek yaparlar. ${ }^{[5]}$ Bu özellikleri nedeniyle son zamanlarda araştırmacılar nöropeptitlerle epilepsi arasındaki ilişkiyi aydınlatmaya odaklanmışlardır. Bu nedenle, nöropeptidler ve reseptörleri yeni antiepileptik ilaçlar geliştirmek için ilgi çekici hedefler olarak görülmektedirler. ${ }^{[5]}$

Pentilentetrazol (PTZ), kemirgenlerde akut nöbetleri indükleyen bir gama-aminobütirik asit reseptör antagonistidir. ${ }^{[7]}$ PTZ, antiepileptik ilaç tarama çalışmalarında sıklıkla kullanılmaktadır. ${ }^{[8]}$ Akut nöbet modeli oluşturmak için PTZ eşik bir dozda (60 ila $100 \mathrm{mg} / \mathrm{kg}$, i.p. veya s.c.) uygulanır. ${ }^{[9]}$ PTZ'nin bu dozlarda akut enjeksiyonu, miyoklonik jerk, klonus ve tonik ekstensiyona yol açar. ${ }^{[9]}$ 


\section{Farelerde PTZ ile İndüklenen Akut Nöbet Modelinde Nesfatin-1'in Doza Bağlı Etkilerinin Değerlendirilmesi}

\section{Öz}

Amaç: Nöropeptidlerin, beyinde inhibitör ve eksitatör sistemler üzerine güçlü modülatör etkilere sahip olduğu bilinmektedir. Serum nesfatin-1 düzeylerinin epileptik hastalarda ve deneysel epilepsi modellerinde arttığı bildirilmektedir. Bununla birlikte, nesfatin-1 uygulamasının akut pentilentetrazol (PTZ) indüklü nöbetler üzerindeki etkileri bilinmemektedir. Bu çalışmanın amacı, nesfatin-1'in farelerde PTZ-indüklü akut nöbet modelinde doza bağımlı etkilerini araştırmaktır.

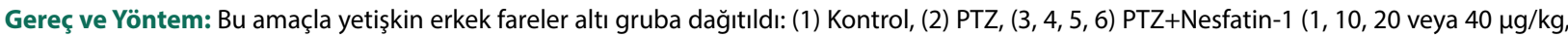
i.p). Kontrol grubundaki farelere sadece serum fizyolojik (SF, $1 \mathrm{ml} / \mathrm{kg}$, i.p) uygulandı. Deney gruplarına nesfatin-1 veya SF uygulandı. Nesfatin-1 veya SF enjeksiyonundan otuz dakika sonra, epileptik nöbetleri indüklemek için tüm deney gruplarına PTZ (80 mg/kg, i.p) enjekte edildi. PTZ enjeksiyonundan sonra ilk miyoklonik jerk (IMJK), jeneralize klonik nöbetler (JKN) ve tonik jeneralize ekstensiyon (TJE) latansları ve TJE süresi belirlendi.

Bulgular: Gruplar arasında IMJK, JKN, TJE latansları ve TJE süresi bakımından anlamlı fark bulunmadı.

Sonuç: Nesfatin-1, tüm dozlarda antikonvülsan veya prokonvülsan etki göstermedi. Sonuç olarak, verilerimiz nesfatin-1 uygulamasının farelerde PTZ ( $80 \mathrm{mg} / \mathrm{kg}$ ) ile indüklenen akut nöbetler üzerinde anti / pro-konvülsan etkisi olmadığını göstermiştir.

Anahtar sözcükler: Nöbet; nöropeptid; pentilentetrazol; PTZ.

Nesfatin-1, (sıklıkla NUCB2 olarak da adlandırılır ${ }^{[10]}$ ) periferik dokular, merkezi ve periferik sinir sistemi tarafından serbestlenen 82 aminoasitli, ${ }^{[1]]}$ yeni keşfedilmiş bir peptiddir. ${ }^{[12]}$ Merkezi olarak önbeyin, arkabeyin, beyin sapı ve spinal korddaki birçok nöronda ekspresse edilmektedir. ${ }^{[13]}$ Hipotalamik yolaklarda, besin alımının düzenlenmesinde ve enerji homeoztazisinde rol oynamaktadır. ${ }^{[13]}$ Nesfatin-1'in, merkezi sinir sistemine ek olarak periferik dokularda da bulunmaktadır. ${ }^{[11]}$ Nesfatin-1, kan-beyin bariyerini aşabilen bir nöropeptiddir. $^{[14]}$

Serum Nesfatin-1 seviyelerinde epilepsi hastalarında ${ }^{[15,16]}$ ve kemirgenlerle yapılan deneysel epilepsi çalışmalarında ${ }^{[17]}$ değişiklikler olduğu bildirilmiştir. NUCB2/nesfatin-1 uygulamasının sıçanlarda epileptik aktiviteye neden olduğu ve penisilin kaynaklı epileptik aktiviteyi artırdığı bildirilmiştir. [18] Bu değişikliklere rağmen Nesfatin-1'in bu alanda çok az çalışılmış olduğu görülmektedir. ${ }^{\left[{ }^{[1]}\right.}$ Yapılan bu çalışmada, Nesfatin-1'in doza bağlı bir biçimde akut PTZ indüklü nöbetler üzerine etkilerinin ortaya konması amaçlandı.

\section{Gereç ve Yöntem}

Hayvanlar- Bu çalışmada 48 adet (2 aylık) erkek fare kullanıldı. Fareler Van Yüzüncü Yıl Üniversitesi Deney Hayvanları biriminden satın alındı. Hayvanlar, standart sıcaklık ve nem koşulları altında ve 12:12 ışık/ karanlık periyodu altında barındırıldı. Fareler ad libitum olarak beslendi. Çalışma prosedürleri Van Yüzüncü Yıl Üniversitesi Deney Hayvanları Etik Kurulu tarafından onaylandı (Tarih: 20.10.2017, Karar No: 2017/10).

Deney protokolü- Fareler randomize olarak altı gruba ayrıldı ( $n=8)$ : (1) Kontrol: SF (1 mL/kg, ip); (2) SF + PTZ: SF (1
$\mathrm{mL} / \mathrm{kg}$, i.p) + PTZ (80 mg/kg, i.p), $(3,4,5,6)$ Nesfatin-1 (1, 10, 20 veya $40 \mu \mathrm{g} / \mathrm{kg}$, i.p) + PTZ (80 mg/kg, ip).

Doza bağımlı etkilerinin tespiti amacıyla nesfatin-1, farkI gruplara $1 \mu \mathrm{g} / \mathrm{kg}^{\left[{ }^{[19]}\right.} 10 \mu \mathrm{g} / \mathrm{kg}, 20 \mu \mathrm{g} / \mathrm{kg}$ veya $40 \mu \mathrm{g} / \mathrm{kg}^{[20]}$ olarak dört farklı dozda enjekte edildi. SF ya da nesfatin-1 enjeksiyonundan 30 dakika sonra tüm gruplara tek doz PTZ (80 mg/kg, ip) $)^{[21]}$ enjeksiyonu yapıldı. PTZ ve Nesfatin-1, $\% 0.9$ serum fizyolojikte (SF) çözüldü. ${ }^{[17,22]}$ PTZ enjeksiyonundan sonra fareler gözlem kafeslerine alınarak $30 \mathrm{dk}$ boyunca gözlendi: ilk miyoklonik jerk (IMJK), jeneralize klonik nöbet (JKN) ve tonik jeneralize ekstensiyon (TJE) latansları ve TJE süreleri kayıt altına alındı. Ekstra 30 dakika da mortalite için gözlem yapıldı.

İstatistiksel analiz- Üzerinde durulan özellikler için tanımlayıcı istatistikler ortalama \pm standart hata (SEM) olarak ifade edildi. Bu özellikler bakımından grupları arası anlamlılığ test etmede (grupları karşılaştırmada) Kruskal Wallis testi kullanıldı. Sağ kalım sayıları bakımından grupları karşılaştırmada tek örnek ki-kare testi yapıldı. Hesaplamalarda istatistik anlamlılık düzeyi \%5 olarak alındı ve hesaplamalar için SPSS istatistik paket programı kullanıldı.

\section{Bulgular}

80 mg/kg, i.p PTZ enjeksiyonu şiddetli nöbetlere yol açtı. Gruplar arasında, IMJK, JKN, TJE latansları ve TJE nöbet süresi bakımından anlamlı bir fark bulunmadı (Şekil 1 ve 2).

Nesfatin-1, $10 \mu \mathrm{g} / \mathrm{kg}$ dozunda uygulandığında IMJ, JKN, TJE latans sürelerinde istatistiksel olarak anlamlı olmasa da bir uzama eğilimi söz konusudur (Şekil 1). Gruplar arasında TJE nöbet süreleri bakımından istatistiksel olarak anlam- 


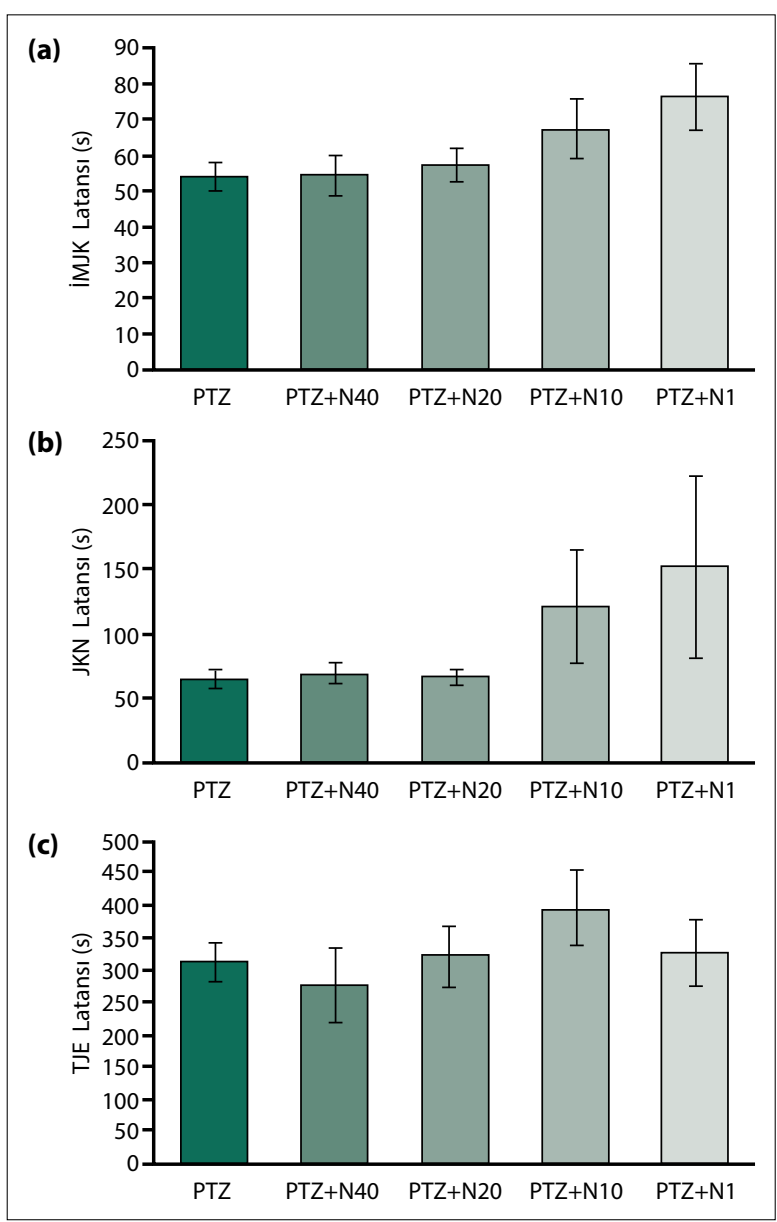

Şekil 1. IMJK (a), JKN (b), TJE (c) Latansları. Veriler ortalama \pm standart hata (SEM) olarak ifade edilmektedir ( $p>0.05$ ). [iMJK: ilk miyoklonik jerk, JKN: jeneralize klonik nöbet, TJE: tonik jeneralize ekstensiyon, PTZ: pentilentetrazol, N1: nesfatin-1 (1 $\mu \mathrm{g} / \mathrm{kg})$, N10: nesfatin-1 $(10 \mu \mathrm{g} / \mathrm{kg})$, N20: nesfatin-1 (20 $\mu \mathrm{g} / \mathrm{kg})$, N40: nesfatin-1 (40 $\mu \mathrm{g} / \mathrm{kg})]$.

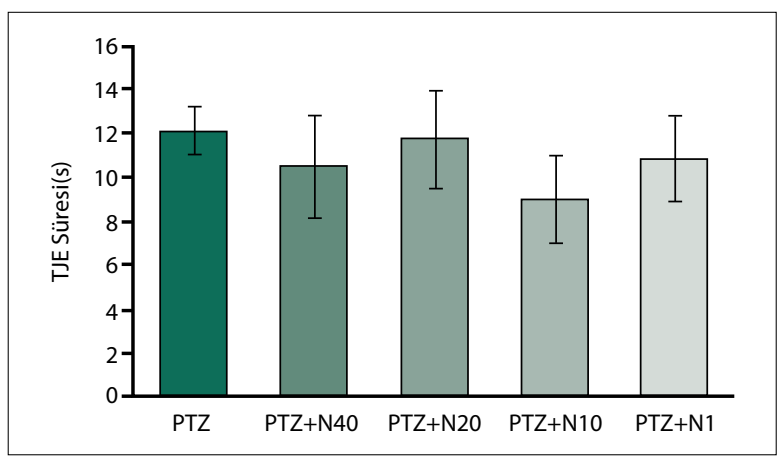

Şekil 2. TJE nöbet süreleri. Veriler ortalama \pm standart hata (SEM) olarak ifade edildi ( $p>0.05)$. [TJE: tonik jeneralize ekstensiyon, PTZ: pentilentetrazol, N1: nesfatin-1 (1 $\mu \mathrm{g} /$ kg), N10: nesfatin-1 (10 $\mu \mathrm{g} / \mathrm{kg})$, N20: nesfatin-1 (20 $\mu \mathrm{g} /$ $\mathrm{kg})$, N40: nesfatin-1 (40 $\mu \mathrm{g} / \mathrm{kg})]$.
Iı bir sonuç bulunmadı (Şekil 2). Deney sonunda hayatta kalan farelerin sayısı, PTZ grubunda $0, \mathrm{PTZ}+\mathrm{N} 1$ grubunda 2, PTZ+ N10 grubunda 2, PTZ+ N20 grubunda 3, PTZ+ N40 grubunda 1 idi. Bununla birlikte sağ kalım sayıları bakımından PTZ, PTZ+N1, PTZ+ N10, PTZ+ N20 ve PTZ+ $\mathrm{N} 40$ grupları arasındaki fark istatistiksel olarak önemsizdir (p>0.05).

\section{Tartışma}

Epileptik nöbetler, uyarılma ve inhibisyon arasındaki hassas dengenin bozulmasından kaynaklanan, anormal aşırı ve senkron nöronal aktiviteden kaynaklanmaktadır. ${ }^{[5]} \mathrm{Nö-}$ ropeptitler, sinaptik iletimin modülasyonuna katılan sinyal molekülleridir, ${ }^{[6]} \mathrm{GABA}$ ve glutamat nörotransmitterleri üzerinde (salınımlarını değiştirerek veya reseptör düzeyinde etkilerini düzenleyerek) güçlü modülatör etkileri mevcuttur ve dolayısıyla inhibisyon ve eksitasyon arasındaki dengeyi etkileyebilirler. ${ }^{[5]}$ Örneğin nöropeptid Y'nin, inhibe edici nörotransmisyonu artırdığı ve uyarıcı nörotransmisyonu azalttığı; enkefalinlerin ise hipokampustaki inhibitör nöronlardan spontan GABA salımını inhibe ettiği ve uyarılabilirliğin artmasına neden olduğu bildirilmektedir. ${ }^{[5]}$

Nesfatin ve epilepsi ile ilgili yapılan çalışmalarda, epilepsi hastalarının serum ve tükürüğünde nesfatin-1 seviyesinde artış olduğu bildirilmiştir. ${ }^{[15]}$ Hayvan çalışmalarında akut PTZ ile indüklenen nöbet modelinde ve PTZ kindling epilepsi modelinde serum nesfatin-1 seviyelerinde artış olduğu bildirilmiştir. ${ }^{[17]}$ Artmış nesfatin-1 düzeylerinin epilepsi patofizyolojisine katkıda bulunabileceği önerilmektedir. ${ }^{[15]}$ NUCB2/nesfatin-1'in sıçanlarda epileptik aktiviteye neden olduğu ve penisilin kaynaklı epileptik aktiviteyi artırdığı bildirilmiştir. ${ }^{[18]}$ Bir başka çalışmada ise $45 \mathrm{mg} / \mathrm{kg}$ dozunda PTZ enjeksiyonu ile oluşturulan modelde nesfatin-1 enjeksiyonun etkileri araştırılmış ve nesfatin-1'in, fenitoin ile sinerjik etkiye sahip olduğu, nöbete bağlı oksidatif beyin hasarında ek bir nöroproteksiyon ile birlikte, anti-nöbet etkisini güçlendirdiği bildirilmiştir. ${ }^{[23]}$ Bizim çalışmamızda nesfatin-1 enjeksiyonu, PTZ ile indüklenen akut nöbetler üzerine 4 farklı dozda, prokonvulsan veya antikonvulsan etki oluşturmadı. Çalışmamızda, Nesfatin-1, $10 \mu \mathrm{g} / \mathrm{kg}$ dozunda uygulandığında IMJK, JKN ve TJE latans sürelerinde bir uzama eğilimi söz konusudur fakat fark istatistiksel olarak anlamlı bulunmadı.

Sonuç olarak nesfatin-1 PTZ indüklenen akut nöbetler üzerinde 4 farklı dozda pro veya antikonvulsan etkiye yol açmadı. Verilerimiz nesfatin-1 uygulamasının tüm nöbet modellerinde prokonvülsan etkiye sahip olmadığını, en azından $80 \mathrm{mg} / \mathrm{kg}$ dozunda PTZ ile indüklenen akut nöbetler üzerinde anti veya prokonvulsan etki göstermediğini ortaya koy- 
maktadır. Fakat bu hipotezi doğrulamak için ek çalışmalara ihtiyaç vardır.

Çalışmamız akut eşik dozda ( $80 \mathrm{mg} / \mathrm{kg}$ ) PTZ indüklü nöbet modelinde nesfatin-1 uygulamasının etkilerini araştıran ilk çalışmadır. Nesfatin-1'in kan-beyin bariyerini geçebildiği bildirilmektedir. ${ }^{[14,24]}$ Bu nedenle bu çalışmada nesfatin-1 intra peritoneal olarak enjekte edilmiştir. Gelecek çalışmalarda tekrarlayan kronik nesfatin-1 uygulamalarının PTZ indüklü nöbet/ epilepsi modellerinde eksitatör veya inhibitör etki gösterip göstermediği araştırılabilir.

Teşekkür- Çalışmanın istatistik analizi için Prof. Dr. Sıddık Keskin'e teşekkür ederiz. Bu çalışma özet halinde Uluslararası Müzik, Dans ve Sağlık Kongresinde (10-13 Ekim 2018, Van, Türkiye) sözlü olarak sunulmuştur.

Ethics Committee Approval- This study approved by the Van Yüzüncü Yıl University Experimental Animals Ethics Committee (Date: 20.10.2017, Decision No: 2017/10).

Peer-review- Externally peer-reviewed.

Conflict of Interest- The authors declare that they have no conflict of interest.

Financial Disclosure: This research was supported by the Research Fund of the Van Yuzuncu Yil University (BAP) of Van Yüzüncü Yıl University with the project number THD2017-6565.

Etik Komite Onayı-Van Yüzüncü Yıl Üniversitesi Deney Hayvanları Etik Kurulu tarafından onaylandı (Tarih: 20.10.2017, Karar No: 2017/10).

Hakem Değerlendirmesi- Dış bağımsız.

Çıkar Çatışması- Yoktur.

Finansal Destek- Bu araştırma, Van Yüzüncü Yıl Üniversitesi Bilimsel Araştırma Projeleri Koordinasyon Birimi (BAP) tarafından THD-2017-6565 numaralı proje olarak desteklenmiştir.

\section{Kaynaklar}

1. Yemadje LP, Houinato D, Quet F, Druet-Cabanac M, Preux PM. Understanding the differences in prevalence of epilepsy in tropical regions. Epilepsia 2011;52(8):1376-81. [CrossRef]

2. Tang F, Hartz AMS, Bauer B. Drug-resistant epilepsy: multiple hypotheses, few answers. Front Neurol 2017;8:301. [CrossRef]

3. Kutlu G, Biçer Gömceli Y, Sanivar F, İnan LE. Türkiye'nin başkenti Ankara'da epilepsinin maliyeti. Epilepsi 2010;16(3):147-52.

4. Kovac S, Walker MC. Neuropeptides in epilepsy. Neuropeptides 2013;47(6):467-75. [CrossRef]

5. Clynen E, Swijsen A, Raijmakers M, Hoogland G, Rigo JM. Neu- ropeptides as targets for the development of anticonvulsant drugs. Mol Neurobiol 2014;50(2):626-46. [CrossRef]

6. Dobolyi A, Kékesi KA, Juhász $G$, Székely $A D$, Lovas $G$, Kovács Z. Receptors of peptides as therapeutic targets in epilepsy research. Curr Med Chem 2014;21(6):764-87. [CrossRef]

7. Zhang B, Wong M. Pentylenetetrazole-induced seizures cause acute, but not chronic, mTOR pathway activation in rat. Epilepsia 2012;53(3):506-11.

8. Erkec $\mathrm{OE}$, Arihan O. Pentylenetetrazole kindling epilepsy model. Epilepsi 2015;21(1):6-12.

9. Dhir A. Pentylenetetrazol (PTZ) kindling model of epilepsy. Curr Protoc Neurosci 2012;9(58): Unit9 37. [CrossRef]

10. Puzio I, Tymicki G, Predka H, Sleboda W, Sobczynska-Wolejszo $M$. Role of nesfatin- 1 in the metabolism of skeletal tissues. Med Weter 2018;74(5):290-94. [CrossRef]

11. Ayada C, Toru U, Korkut Y. Nesfatin-1 and its effects on different systems. Hippokratia 2015;19(1):4-10.

12. Oh-I S, Shimizu H, Satoh T, Okada S, Adachi S, Inoue K, et al. Identification of nesfatin-1 as a satiety molecule in the hypothalamus. Nature 2006;443(7112):709-12. [CrossRef]

13. Pałasz A, Krzystanek M, Worthington J, Czajkowska B, Kostro K, Wiaderkiewicz $R$, et al. Nesfatin-1, a unique regulatory neuropeptide of the brain. Neuropeptides 2012;46(3):105-12.

14. Price TO, Samson WK, Niehoff ML, Banks WA. Permeability of the blood-brain barrier to a novel satiety molecule nesfatin-1. Peptides 2007;28(12):2372-81. [CrossRef]

15. Aydin S, Dag E, Ozkan Y, Erman F, Dagli AF, Kilic N, et al. Nesfatin-1 and ghrelin levels in serum and saliva of epileptic patients: hormonal changes can have a major effect on seizure disorders. Mol Cell Biochem 2009;328(1-2):49-56. [CrossRef]

16. Aydin S, Dag E, Ozkan Y, Arslan O, Koc G, Bek S, et al. Time-dependent changes in the serum levels of prolactin, nesfatin-1 and ghrelin as a marker of epileptic attacks young male patients. Peptides 2011;32(6):1276-80. [CrossRef]

17. Ergul Erkec $O$, Algul S, Kara M. Evaluation of ghrelin, nesfatin-1 and irisin levels of serum and brain after acute or chronic pentylenetetrazole administrations in rats using sodium valproate. Neurol Res 2018;40(11):923-9. [CrossRef]

18. Erken HA, Koc ER, Erken G, Genc O, Celik HT, Gokce EC, et al. Proconvulsant Effect of NUCB2/Nesfatin-1. Int J Pept Res Ther 2015;21(1):29-38. [CrossRef]

19. Kolgazi M, Cantali-Ozturk C, Deniz R, Ozdemir-Kumral ZN, Yuksel M, Sirvanci S, et al. Nesfatin-1 alleviates gastric damage via direct antioxidant mechanisms. J Surg Res 2015;193(1):111-8.

20. Ge JF, Xu YY, Qin G, Pan XY, Cheng JQ, Chen FH. Nesfatin-1, a potent anorexic agent, decreases exploration and induces anxiety-like behavior in rats without altering learning or memory. Brain Res 2015;1629:171-81. [CrossRef]

21. Kumar A, Lalitha S, Mishra J. Hesperidin potentiates the neuroprotective effects of diazepam and gabapentin against pentylenetetrazole-induced convulsions in mice: Possible behavioral, biochemical and mitochondrial alterations. Indian J Pharmacol 2014;46(3):309-15. [CrossRef] 
22. Ge JF, Xu YY, Qin G, Peng YN, Zhang CF, Liu XR, et al. Depressionlike Behavior Induced by Nesfatin-1 in Rats: Involvement of Increased Immune Activation and Imbalance of Synaptic Vesicle Proteins. Front Neurosci 2015;9:429. [CrossRef]

23. Arabacı Tamer S, Koyuncuoğlu T, Karagöz A, Akakın D, Erzik C, Yüksel $M$, et al. The combination of nesfatin-1 and phenytoin has a synergisticeffect in improving seizure-induced neuronal damage andmemory dysfunction in rats. Acta Physiologica 2016;218(S709):9.
24. Pan W, Hsuchou H, Kastin AJ. Nesfatin-1 crosses the bloodbrain barrier without saturation. Peptides 2007;28(11):2223-8. 